\title{
RPS6KA1 Gene
}

National Cancer Institute

\section{Source}

National Cancer Institute. RPS6KA1 Gene. NCI Thesaurus. Code C104764.

This gene is involved in controlling cell growth and differentiation. 